\title{
CURRENT STATE AND TRENDS OF OPENNESS OF THE UKRAINIAN ECONOMY
}

\author{
IRYNA ANKHELKO, IRYNA LEKH
}

\begin{abstract}
The essence of openness of the economy as an object of theoretical study based on the analysis of publications and research of domestic and foreign scientists is explored in the article. On that basis, the authors give their interpretation of the concept. It is noted that the consistent expansion of economic openness is an important factor in modern economic development. Four groups of the division of national economies by the criterion of openness, namely by the share of exports in the country's GDP, are considered. The main conditions of an open economy are highlighted and the main tools (economic and political) with which it is possible to achieve the expansion of economic openness are given.

An assessment of the current state and trends of openness of the national economy, based on the analysis of the main indicators of exports and imports of goods and services, as well as the geographical structure of Ukraine's foreign trade by recipient countries and donor countries of goods and services, has been made. It was found that in the current conditions of socio-economic instability, the openness of Ukraine's economy remains at a fairly high level, which causes its close dependence on changes in external conditions. It is analyzed that the lion's share in the overall structure of Ukraine's foreign trade belongs to goods. The principal recipient countries of Ukrainian goods and services and donor countries in 2020 have been identified. The most common goods and services in the structure of exports and imports of Ukraine are also highlighted. In particular, it is noted that the most common goods for export were products of plant origin, base metals and articles base metals, fats and oils of animal or vegetable origin, and among services transport services. At the same time, it was determined that the highest volume of imports in the general structure of Ukraine's foreign trade was achieved via machinery, equipment and machinery, electrical equipment and transport services import. It is generalized that the openness of Ukraine's economy is essential for its socio-economic development. Importantly to maximise the use of openness advantages that leads to productivity increasing and adaptation of production to growing competition that in turn is an important factor in improving the overall efficiency of the economy. It is recommended for ensuring the economic development of Ukraine, along with the foreign trade component of economic openness, it is also necessary to develop financial (including investment, technological, communicational) and political components.
\end{abstract}

Keywords: openness of economy, open economy, exports, imports, GDP, foreign trade policy, economic growth.

JEL Classification: F410, O190. 


\section{INTRODUCTION}

The necessary condition for supporting sustainable economic development is to ensure access to the components of modern production. As it is well known, such components are raw materials, capital, skilled labour, technology, management and others. Facilitating access to these factors means that they become relatively cheaper. The goods and services will be produced at relatively lower costs, therefore. This approach will increase the competitiveness and efficiency of the economy, ensuring higher rates of economic growth. It is generally accepted that the relative prices of both factors (components) of production and products are lower in terms of free trade. That is why the consistent expansion of economic openness is an important factor in modern economic development. The main sense of economic openness is promoting the free movement of factors of production (exports/imports) and reducing (until the complete elimination) of restrictions and barriers, primarily related to trade in goods and services [1, p. 4].

In the context of globalization, there is a general tendency to increase the openness of national economies. Orientation to foreign markets becomes a powerful stimulus for the development of the national economy in a favourable external environment.

\section{THEORETICAL BACKGROUND}

A large number of publications and researches of domestic and foreign scientists, in particular, are devoted to the issue of openness of national economies, in particular H. Anilovska [2], $\mathrm{O}$. Amosha, V. Bazylevych, S. Bila [3], M. Butka, O. Danylenko [4], M. Dolishnii, O. Kremen, S. Nosova [5], O. Sanina [6], N. Hofman, C. Graebner (C. Gräbner) [7], P. Heimberger [7], J. Kapeller [7], Ya. Keho [9], E. Mehic [8], P. Omoke, S. Opuala-Charles [10], M. Porter, D. Rikardo, S. Silajdzic [8], A. Smit, F. Springholz [7] etc. In their works, the authors comprehensively explore the openness of national economies, focusing on their nature, types, factors and main manifestations, as well as indicators of analysis and areas of evaluation. In particular, C. Graebner, P. Heimberger, J. Kapeller та F. Springholz (2021) in their works consider measures of economic openness, the latter being understood as the degree to which non-domestic actors can or do participate in a domestic economy. Based on the existing literature, the authors introduce a typology of openness indicators, which distinguishes between «real» and «financial» openness as well as «de-facto» and «de-jure» measures of openness. They use data collected on these indicators to analyze trends in openness over time and conduct correlation analysis across indicators. Finally, they illustrate the potential consequences of employing different openness measures in a growth regression framework [7, p. 88-110]. S. Silajdzic, E. Mehic (2018), Ya. Keho (2017), P. Omoke, S. Opuala-Charles (2021) consider economic openness through the prism of the relationship with economic growth. According to scientists, trade openness always leads to economic efficiency [8-10]. However, S. Silajdzic and E. Mehic (2018) note that market imperfections, differences in technology and endowments may lead to the adverse effect of trade liberalisation on individual countries [8]. The ambiguity of the consequences of economic openness is also mentioned in the publication Department for Business, Innovation and Skills (2011) [11]. Despite the significant amount of works devoted to the study of economic openness, some issues of this problem remain open and require more detailed study and analysis.

\section{Research ObJective, Methodology and Data}

The purpose of the article is to study the essence of openness of the economy as an object of theoretical study and the institution of promoting economic development of the country, as well as to determine the state and trends of economic openness of Ukraine in modern economic conditions.

General and special methods of cognition were used for achieving the goal. In particular: the dialectical method, methods of comparison and generalization, grouping and systematization, analysis and synthesis, methods of the tabular and graphical display of research results. The use of dialectical 
cognition methods, comparison and generalization helped determine the main conditions of openness, the main tools (economic and political) of its expansion and the mechanisms of interrelation with economic growth.

\section{RESUlTS AND DiscUSSION}

The current state and trends of openness of the national economy were assessed by the analysis of the main indicators of exports and imports of goods and services, as well as the geographical structure of Ukraine's foreign trade.

The information bases of the study were the works of domestic and foreign scientists, data from domestic and international organizations, periodicals.

First of all, it should be noted that in modern economic literature, economic openness is considered in a fairly broad sense. Some scientists identify it with globalization, others - with the state of the national economy.

Thus, according to S. Bila, an open economy is a state of free interaction of the national economy with the economies of other countries, which arises based on the free movement of goods, resources, labour, capital, income, investment. The intensity of these movements determines the degree of openness of the national economy, which is closely related to both the level of development of productive forces and the country's place in the system of the international division of labour [3, p. 11]. C. Nosova considers economic openness as a condition under which any economic entity has the right to conduct foreign trade operations, i.e. foreign legal entities and individuals on equal terms with all producers operate in the domestic market per national law and international norms [5]. According to the definition of $\mathrm{H}$. Feihin, an open economy is a system of markets in which the foreign sector is represented [12]. A similar definition of an open economy in her works gives O. Danylenko, who believes that an open economy is a national economy that has a high degree of involvement in international economic relations [4]. According to H. Anilovska, the openness of the economy is determined by the whole set of economic interactions with foreign countries: capital migration, scientific and technical exchange, movement of labour, currency relations and, of course, trade. It can be formulated as a free flow of goods, capital, human resources, information between individual countries [2, p. 37-38]. O. Sanina and Yu. Kiriienko interpret the open economy as a national economic system that takes an active part in world trade and is part of the world economy, characterized by an effective combination of observed openness and openness policy [6, p. 163].

In our opinion, an open economy is a national economy, which is connected with other countries by the free and intensive movement of factors of production, goods and services. In its development, it uses not only national opportunities but also the advantages of the international division of labour and other factors of production.

In general, summarizing the definitions of open economy proposed by various scientists, we can identify the following main conditions:

- favourable tariff and non-tariff state regulation of foreign trade;

- favourable investment climate, which encourages investors to work in the domestic market of a country;

- the possibility of access of foreign labour, systems and technologies, information and management experience to the domestic market.

Along with the main conditions of economic openness, it is also advisable to identify the main tools (economic and political) with which it is possible to achieve the expansion of economic openness [13, p. 22]:

- $\quad$ reduction (and further abolition) of barriers (including customs) for foreign economic activity of both domestic and foreign business;

- transparent and non-discriminatory application of foreign economic legislation;

- simplification of customs administration; 
- harmonization of national standards and procedures of technical regulation with international ones;

- elimination of excessive currency regulation and control;

- facilitating foreign exchange transactions related to capital movements, etc.

Worth noting that the degree of openness of the national economy determines by a system of macroeconomic indicators that are subject to comparison. Most often, the criterion of openness of the national economy is the indicator of the share of exports in the country's GDP - the coefficient of export openness. According to the World Bank, in keeping with this criterion [14]:

- the highest openness group "open economies" includes economies with more than $35 \%$ of the share of exports in the GDP of the country;

- the group of "fairly open economies" - includes economies with a ratio of 25 to $35 \%$ of the share of exports in GDP;

- the group of "moderately open economies" - includes economies with a ratio of 10 to $25 \%$ of the share of exports in GDP;

- the lower group of "relatively closed economies" - includes economies with less than $10 \%$ of the share of exports in GDP.

The leaders in "economic openness" are the economies of developed countries, including the USA, $\mathrm{EU}$, as well as the economies of the leading countries of the "new industrial development" (China, Singapore, South Korea, etc.) [3, p. 13].

Assessing the openness of Ukraine's economy, worth noting that in the current conditions of socioeconomic instability, it remains at a fairly high level, which causes its close dependence on changes in external conditions. In general, according to the State Statistics Service of Ukraine (Table 1, Fig. 1), in 2020, for the first time in recent years, despite the reduction in total exports and imports, a positive foreign trade balance of 1,079.5 million USD was achieved.

\begin{tabular}{|c|c|c|c|c|c|c|c|}
\hline \multirow{2}{*}{ Years } & \multicolumn{3}{|c|}{ Goods } & \multicolumn{3}{c|}{ Services } & $\begin{array}{c}\text { Foreign } \\
\text { Trade } \\
\text { balance } \\
(+,-)\end{array}$ \\
\cline { 2 - 7 } & export & import & $\begin{array}{c}\text { Balance } \\
(+,-)\end{array}$ & export & import & $\begin{array}{c}\text { Balance } \\
(+,-)\end{array}$ & 4824,4 \\
\hline 2015 & 38127,1 & 37516,4 & 610,7 & 9736,7 & 5523,0 & 4213,7 & 1653,4 \\
\hline 2016 & 36361,7 & 39249,8 & $-2888,1$ & 9868,0 & 5326,5 & 4541,5 & $-1104,2$ \\
\hline 2017 & 43264,7 & 49607,2 & $-6342,5$ & 10714,4 & 5476,1 & 5238,3 & $-4523,4$ \\
\hline 2018 & 47335,0 & 57187,6 & $-9852,6$ & 11638,0 & 6308,8 & 5329,2 & $-2058,9$ \\
\hline 2019 & 50054,6 & 60800,2 & $-10745,6$ & 15628,9 & 6942,2 & 8686,7 & 1079,5 \\
\hline 2020 & 49212,9 & 54091,3 & $-4878,4$ & 11167,1 & 5209,2 & 5957,9 & \\
\hline
\end{tabular}

Tab.1. The main indicators of Ukraine's foreign economic activity in terms of exports/imports of goods and services in 2015 - 2020 (in million USD) [15]. 


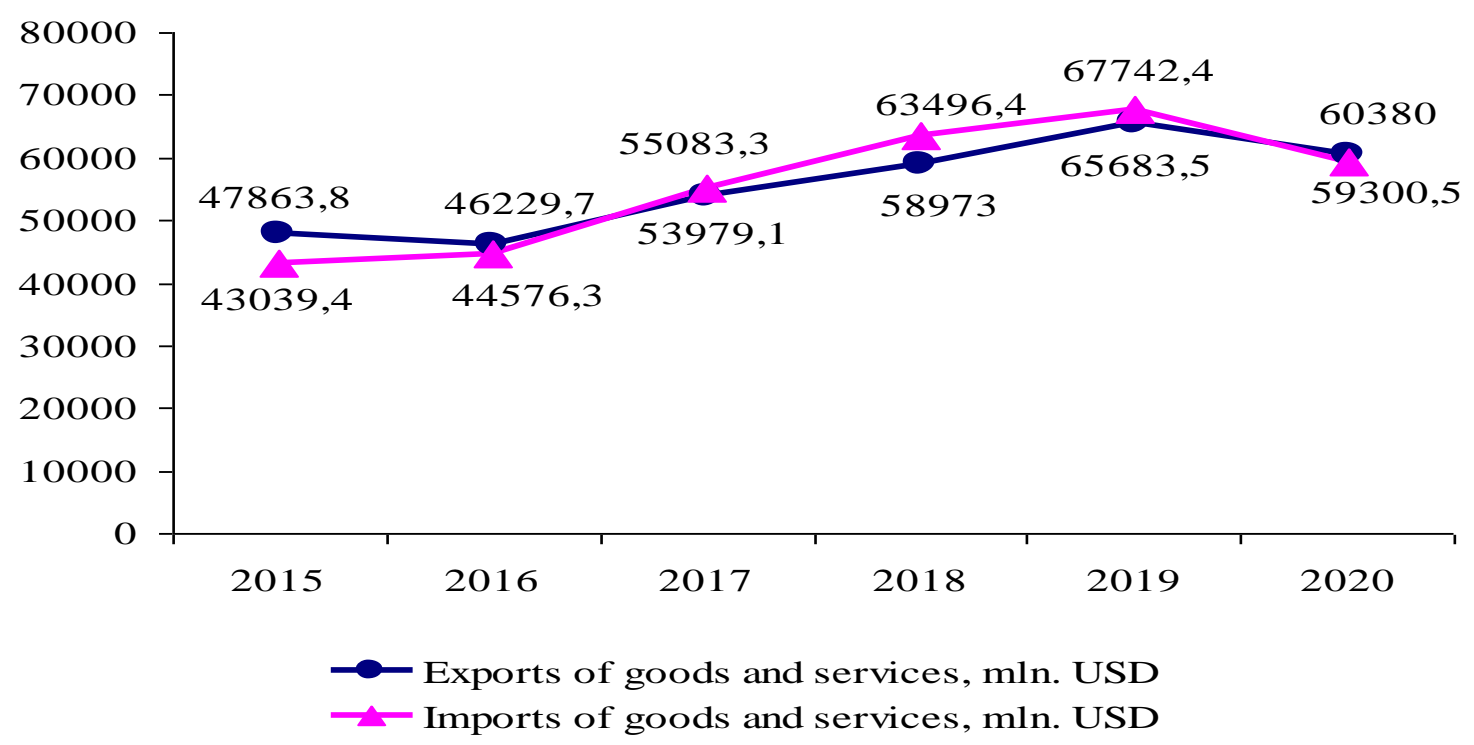

Fig. 1. Dynamics of exports and imports of goods and services during 2015 - 2020 (in million USD) [15].

In general, according to the data, in 2020 compared to 2019, exports of goods and services decreased by 5303.5 million USD (or $8.07 \%$ ), imports of goods and services - by 8441.9 million USD (or $12.46 \%$ ). The positive balance of foreign trade was achieved due to the services sector - the volume of exports exceeded the volume of imports by 5957.9 million USD (or 114.37\%) and covered the negative balance of foreign trade in goods in the amount of 4878.4 million USD.

The lion's share in the overall structure of Ukraine's foreign trade belongs to goods (Fig. 2), despite the achievement of a positive balance at the expense of services. Thus, in the total volume of exports, goods occupy $81.5 \%$ (in $2019-76.2 \%$ ), in the total volume of imports $-91.2 \%$ (in $2019-89.8 \%$ ).

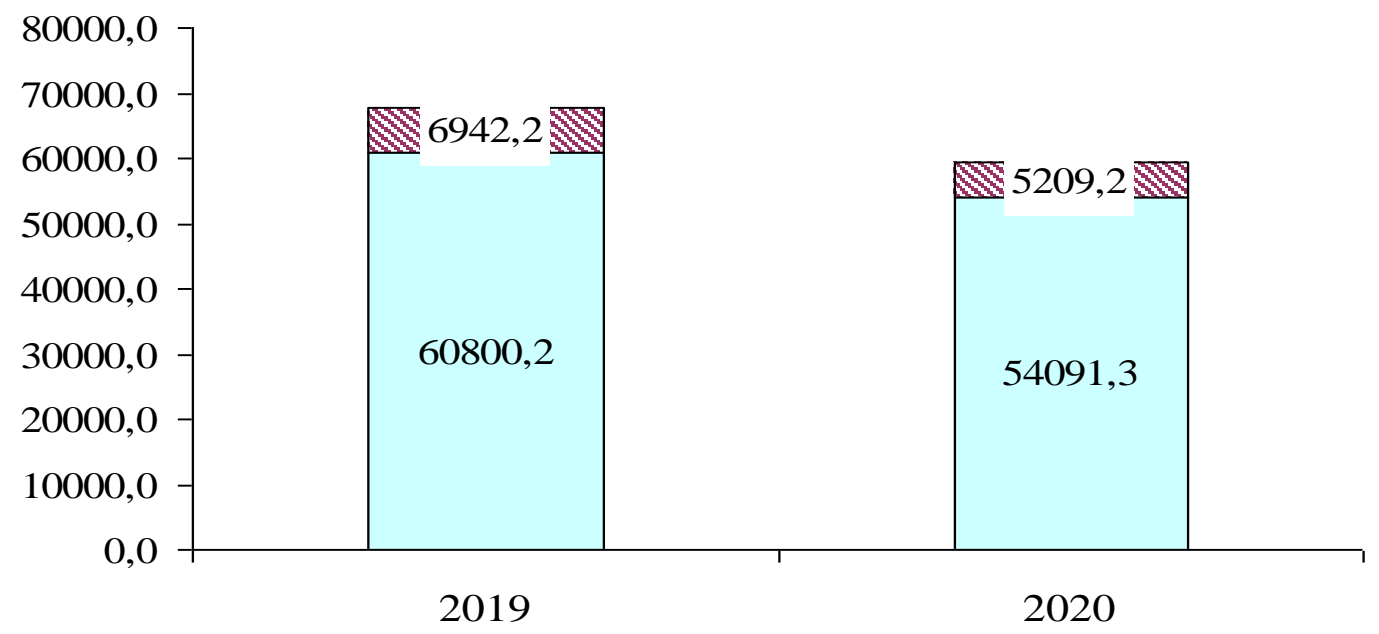

Imports of goods, mln. USD $\$$ Imports of services, mln. USD

Fig. 2. Comparative dynamics of exports and imports for 2019-2020 [15].

In 2020 the main recipient countries of goods, according to the analysis of the geographical structure of Ukraine's foreign trade, were [15]:

of goods

- China (7112.7 million USD or $14.45 \%$ of total exports of goods);

- Poland (3273.2 million USD or 6.65\% of total exports of goods); 
- $\quad$ the Russian Federation (2706.01 million USD or 5.5\% of total exports of goods);

of services

- the Russian Federation (2619.1 million USD or $23.45 \%$ of total services exports);

- $\quad$ the USA (1389.2 million USD or $12.44 \%$ of total services exports);

- Switzerland (732.0 million USD or $6.56 \%$ of total services exports).

The most common goods for export were [15]:

- products of plant origin ( $24.16 \%$ of total exports of goods);

- base metals and articles of base metals (18.35\% of total exports of goods);

- fats and oils of animal or vegetable origin ( $11.70 \%$ of the total volume of exports of goods).

Among services, the most exported were [15]:

- transport services (43.70\% of total exports of services);

- telecommunications, computer and information services (26.06\% of total exports of services);

- $\quad$ services for processing of material resources (12.05\% total exports of services).

The main donor countries in 2020 were the unchanging leaders (in recent years) [15]:

of goods

- China (8305.69 million USD or 15.35\% of total imports of goods (in 2019 - 9204.8 million USD $(15.1 \%))$;

- Germany (5337.95 million USD or 9.87\% of total imports of goods (in $2019-5986.9$ million USD $(9.8 \%))$;

- the Russian Federation (4542.39 million USD or $8.40 \%$ of total imports of goods (in $2019-6985.0$ million USD (11.5\%));

of services

- the United Kingdom of Great Britain and Northern Ireland (467.47 million US dollars or 9.0\% of total imports of services);

- $\quad$ the USA (454.27 million USD or 8.7\% of total imports of services);

- $\quad$ Turkey (426.04 million USD or 8.2\% of total imports of services).

The largest volume of imports was achieved in the import of [15]:

- machinery, and mechanical appliances, electrical equipment (11544.17 million USD or $21.34 \%$ of total imports of goods);

- mineral products (8402.74 million USD or $15.53 \%$ of total imports of goods);

- chemical and related products (7331.5 million USD or $13.55 \%$ of total imports of goods).

Among services, the largest volume of imports was achieved in the import of [15]:

- transport services (1013.62 million USD or $19.46 \%$ of total imports of services);

- business services ( 972.97 million USD or $18.68 \%$ of total imports of services);

- $\quad$ state and government services (737.49 million USD or 14.16\% of total imports of services).

\section{CONCLUSIONS}

Worth noting that the openness of Ukraine's economy is essential for its socio-economic development. Today it is necessary to maximise the use of openness advantages because it leads to productivity increasing and adaptation of production to growing competition. That is consistent with the economic postulate - the higher share of imports in domestic use positively correlates with the level of labour productivity. And it is a significant factor in the overall efficiency of the economy, which will ultimately maintain (intensify) economic growth. Besides the increasing competition, which leads to increased productivity in the domestic market, openness helps to improve innovation, increasing investment, opens new opportunities for sales (exports), as well as creates an affordable and better range of raw materials for producers. However, it is worth remembering that openness by itself is not a sufficient condition for accelerating economic growth. It is interlinked with the establishment of certain institutions (primarily the institution of private property), ensures due jurisdiction and political stability, and must be accompanied by macroeconomic stability. 
Thus, to ensure the economic development of Ukraine, along with the foreign trade component of economic openness, it is also necessary to develop financial (including investment, technological, communicational) and political components.

\section{REFERENCES}

[1] Global trends in the development of integration processes: Analytical report of the Razumkov Center. National security and defense, 7 (91) (2007), 3-24. (in Ukrainian)

[2] Anilovska H. Ia. Open economy: problems of economic security. Scientific Bulletin of Lviv State University of Internal Affairs, 1 (2009), 36-47. (in Ukrainian)

[3] Bila S.O. Current trends in the development of foreign trade relations and the risks of neoprotectionism. Development strategy of Ukraine, 1 (2017), 11-16. (in Ukrainian)

[4] Danylenko O.L. Open economy as a prerequisite for the interaction of domestic and foreign markets. Available at: http://www.rusnauka.com/ONG/Economics/2_danilenko o.1..doc.htm.

[5] Nosova C.S. Economic theory: textbook for universities. Vlados, Moscow, 1999. (in Russian)

[6] Sanina O.R., Kiriienko Yu.A. Indicators for assessing the openness of the economic system of Ukraine. Management and entrepreneurship in Ukraine: stages of formation and problems of development, 2011, 158-166. (in Ukrainian)

[7] Gräbner C., Heimberger Ph., Kapeller J., Springholz Fl. Understanding economic openness: a review of existing measures. Review of World Economics, (2021), 87-120.

[8] Silajdzic S., Mehic E. Trade Openness and Economic Growth: Empirical Evidence from Transition Economies, Trade and Global Market. (2018).Available at: https://www.intechopen.com/books/tradeand-global-market/trade-openness-and-economic-growth-empirical-evidence-from-transitioneconomies. doi: 10.5772/intechopen.75812.

[9] Keho Ya. The impact of trade openness on economic growth: The case of Cote d'Ivoire. Cogent Economics $\mathcal{E} \quad$ Finance, $\quad 5$ (2017). Available at: https://www.tandfonline.com/doi/pdf/10.1080/23322039.2017.1332820?needAccess=true. doi: 10.1080/23322039.2017.1332820.

[10] Omoke P.C., Opuala-Charles S. Trade openness and economic growth nexus: Exploring the role of institutional quality in Nigeria. Cogent Economics \& Finance, 9:1 (2021). Available at: https://www.tandfonline.com/doi/pdf/10.1080/23322039.2020.1868686?needAccess=true. doi: $10.1080 / 23322039.2020 .1868686$

[11] Economic openness and economic prosperity. Trade and Investment Analytical Papers Topic 2 of 18. BIS. 2011. Available at:

https://assets.publishing.service.gov.uk/government/uploads/system/uploads/attachment_data/file/433 12/11-721-economic-openness-and-prosperity.pdf

[12] Feihin H.F. Open Economy: a macroeconomic approach: a textbook. SPBGUEF Publishing House, St. Petersburg, 2000. (in Russian)

[13] Anhelko I.V., Lekh I.A., Pecherytsia I.B. Current state of openness of the national economy of Ukraine. Bulletin of Khmelnytsky National University, 3 (282) (2020), 21-24. (in Ukrainian)

[14] A World Bank Group Flagship Report. Doing Business 2017 Equal Opportunity for All. International Bank for Reconstruction and Development/ The World Bank, Washington, 2016

[15] Foreign economic activity. State Statistics Service of Ukraine. Available at: http://www.ukrstat.gov.ua/. 
Address: Iryna Ankhelko, Iryna Lekh, Lviv Polytechnic National University, 12, Stepana Bandera Str., Lviv, 79000 Ukraine.

E-mail: iryna.v.anhelko@lpnu.ua, iryna.a.lekh@lpnu.ua.

Received: August 27, 2021; revised: September 29, 2021.

Ангелко Ірина, Лех Ірина. Сучасний стан та тенденції відкритості економіки України. Журнал Прикарпатського університету імені Василя Стефаника, 8 (3) (2021), 68-75.

У статті досліджено сутність відкритості економіки як об'єкта теоретичного вивчення на основі аналізу публікацій та досліджень вітчизняних і зарубіжних науковців та наведено власне трактування досліджуваного поняття. Зазначено, що вагомим чинником сучасного економічного розвитку $\epsilon$ послідовне розширення економічної відкритості. Розглянуто чотири групи поділу національних економік за критерієм відкритості, а саме за показником частки експорту у ВВП країни. Виокремлено основні умови відкритої економіки та наведено головні інструменти (економічного та політичного характеру) за допомогою яких можна досягти розширення економічної відкритості.

Здійснено оцінку сучасного стану та тенденцій відкритості національної економіки на основі аналізу основних показників експорту та імпорту товарів та послуг, а також географічної структури зовнішньої торгівлі України в розрізі країн-реципієнтів та країн-донорів товарів та послуг. Виявлено, що в сучасних умовах соціально-економічної нестабільності відкритість економіки України залишається на досить високому рівні, що спричиняе іiі тісну залежність від зміни зовнішньої кон'юнктури. Проаналізовано, що левова частка у загальній структурі зовнішньої торгівлі України належить товарам. Виокремлено основні країни-реципієнти українських товарів та послуг та країни донори у 2020 році. Також виокремлено найбільш поширені товари та послуги у структурі експорту та імпорту України. Зокрема зазначено, що найбільш поширеними товарами для експорту виявилися: продукти рослинного походження, недорогоцінні метади та вироби 3 них, жири та олії тваринного або рослинного походження; серед послуг - транспортні послуги. Разом з тим визначено, що найбільший обсяг імпорту в загальній структурі зовнішньої торгівлі України був досягнутий при імпорті машин, обладнання та механізмів, електротехнічного обладнання та транспортних послуг. Узагальнено, що відкритість економіки України має важдиве значення для ії соціально-економічного розвитку. Важливо, максимально використовувати переваги відкритості, що зумовдює підвищення продуктивності праці та адаптації виробництва до зростаючої конкуренції, і відповідно є вагомим чинником загального підвищення ефективності економіки. Рекомендовано 3 метою забезпечення економічного розвитку України поряд із зовнішньоторговельною складовою відкритості економіки також розвивати фінансову (зокрема інвестиційну, технологічну та комунікаційну) та політичну.

Ключові слова: відкритість економіки, відкрита економіка, експорт, імпорт, ВВП, зовнішньоторговельна політика, економічне зростання. 